\title{
A CASE OF OVARIAN DYSGERMINOMA WITH GONADAL DYSGENESIS IN 29-YEAR-OLD WOMAN WITH 46,XX KARYOTYPE
}

\author{
So-yeon Yoon, MD', Hyang Gi Park, MD', Jin Yi Kuk, MD', Soon Ae Oak, MD², Jong Hoon Park, MD \\ ${ }^{1}$ Department of Obstetrics and Gynecology, Samsung Medical Center, Sungkyunkwan University School of Medicine, Seoul; Departments of ${ }^{2}$ Pathology, ${ }^{3}$ Obstetrics \\ and Gynecology, Ilsin Christian Hospital, Busan, Korea
}

Gonadal dysgenesis occurs in rare case of ovarian tumor. Most tumors associated with gonadal dysgenesis were gonadoblastomas and dysgerminomas. In addition, premature ovarian insufficiency associated with these ovarian tumors in normal chromosomal type had not reported in many cases. A 29-year-old nulligravida woman who was concurrented with ovarian dysgerminoma and fibroma is presented. Measurements were made on serum lactate dehydrogenase, CA-125, CA 19-9 and pelvis ultrasonography and computed tomography. The clinical stage was IA and right salpingo-oophorectomy and wedge resection of the left ovary were done. On laboratory finding after operation on her serum follicular stimulating hormone was increased and $E_{2}$ was decreased. The result of chromosomal analysis was $46, \mathrm{XX}$, normal. We represent here with brief review of literature one case of gonadal dysgenesis in nulligravida woman, associated with dysgerminoma, with normal karyotype.

Keywords: Dysgerminoma; Gonadal dysgenesis; Normal karyotype

성선 이형성(gonadal dysgenesis)은 비정상적으로 발달된 생식선 이 삭상 성선으로 남은 것으로, 뇌하수체와 성선의 되먹임(feedback) 작용으로 인하여 황체호르몬(luteinizing hormone)과 난포자극호르몬 (follicle-stimulating hormone)의 혈중 농도가 상승되는 것을 특징으로 한다. 성선 이형성과 연관된 일차성 무월경을 가진 여성의 $30 \%$ 에서 염 색체 이상을 보이고[1], 그 중 45,X의 핵형을 가진 터너증후군(Turner syndrome)과 이의 변형 핵형이 가장 흔하지만, $X$ 염색체의 구조 이상 과 모자이시즘, 완전 성선 이형성, 정상 여성호르몬(estrogen) 분비를 방해하는 효소 이상과도 관련이 있다.

대개 일측은 이형성 성선(dysgenetic gonad)이고 반대편은 삭상 성 선를 가지는 경우가 가장 많고, 신생아 시기에는 모호한 외부 생식기가 내원하게 되는 가장 흔한 주소이고, 이후에는 지나치게 작은 키와 림프 부종 등의 외향적인 터너징후나 일차성 무월경이 흔한 주소이다[2].

성선 이형성 환자에서 난소종양이 드물게 동반되는데, 동반되는 종양 중 난소 미분화세포종(dysgeminoma)과 성선 아세포종(gonadoblastoma) 이 가장 흔하며, 이들 종양은 난소 생식선에서 발생하는 악성 종양 중 가장 흔하고, 전체 난소암의 $2 \%$ 정도를 차지한다[3,4]. 아직도 명확한 발병기전이 규명된 것은 아니지만, $Y$ 염색체나 $Y$ 모자이시즘이 성선 이형성과 난소 미분화세포종 발생에 크게 관여하는 것으로 알려져 있 다[5].

본 증례는 임신력이 없는 29세 여성에서 일측 난소 미분화세포종과
편측 난소의 섬유종 및 난소부전이 동반된 경우로, $Y$ 염색체 관련 인자 가 발견되지 않은 정상 염색체 형을 보이는 매우 드문 예이다.

\section{증 례}

환 자: 박 00,29 세

산과력: 0-0-0-0, 미혼

Received: 2012.4.30. Revised: 2012.7.10. Accepted: 2012.8.27. Corresponding author: So-yeon Yoon, MD

Department of Obstetrics and Gynecology, Samsung Medical Center, Sungkyunkwan University School of Medicine, 81 Irwonro, Gangnam-gu, Seoul 135-710, Korea Tel: +82-2-3410-3518 Fax: +82-2-3410-0630 E-mail: soyeon.yoon@samsung.com

This is an Open Access article distributed under the terms of the Creative Commons Attribution Non-Commercial License (http://creativecommons.org/licenses/ by-nc/3.0/) which permits unrestricted non-commercial use, distribution, and reproduction in any medium, provided the original work is properly cited.

Copyright (C) 2012. Korean Society of Obstetrics and Gynecology 

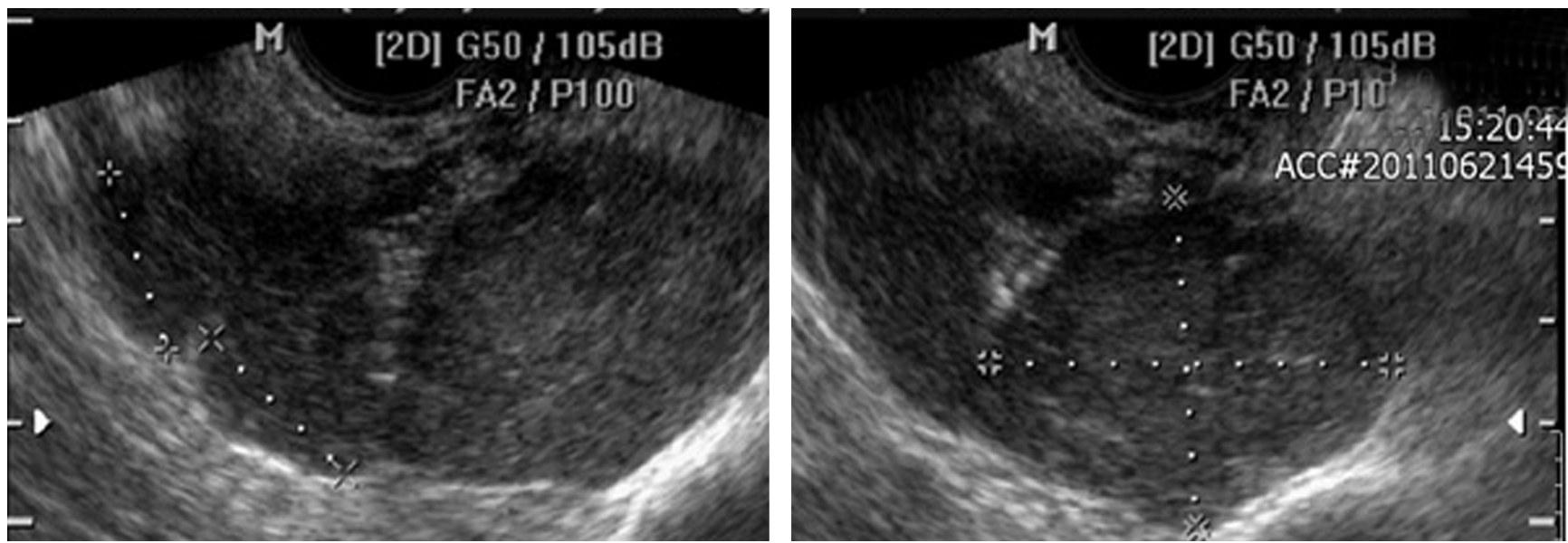

Fig. 1. Right ovarian tumor finding: transvaginal ultrasound.

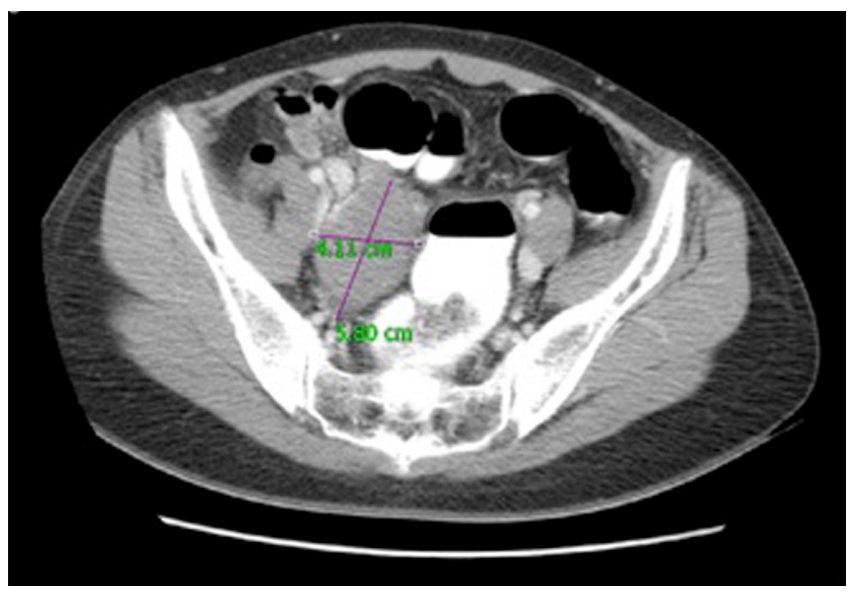

Fig. 2. Abdomen-pelvis computed tomography.

월경력: 초경은 중학교 2 학년 때 있었고 환자의 월경주기는 30 일 정도 로 비교적 규칙적이라고 말하였으나, 문진상 그 양상은 일정하지 않았 으며 최종 월경일은 2011년 6월 11일이었다.

가족력: 특이사항 없었다.

과거력: 특이사항 없었다.

현 병력: 내원 1년 전부터 생리가 심하게 불규칙해져 타 병원을 방문 하여 시행한 진찰 소견상 특이 소견 없었다고 하였다. 생리불순이 지속 되어 2011년 5월 방문한 타 병원에서 초음파를 시행 후 $5 \mathrm{~cm}$ 크기의 복합음영을 보이는 난소종양 확인 후 경구 피임약 처방받아 복용하던 중 2011년 6월 11일 소퇴성 출혈을 시작하여 2011년 6월 20일 출혈 이 끝난 후 추적관찰상 $5 \mathrm{~cm}$ 다음영 난소종양이 지속되어 2011년 6월 21일 본원으로 전원되었다.

검사 소견: 일반 혈액검사상 백혈구 $5,700 / \mathrm{mm}^{3}$, 혈색소 $12.9 \mathrm{~g} / \mathrm{dL}$, 적 혈구 용적 40.3\%, 혈소판 244,000/mL이었다. Lactate dehydrogenase $371 \mathrm{U} / \mathrm{mL}, \mathrm{CA}-12514.8 \mathrm{U} / \mathrm{mL}, \mathrm{CA}$ 19-9 $12.43 \mathrm{U} / \mathrm{mL}$, CEA 1.94 $\mathrm{IU} / \mathrm{mL}$ 였다. Urine hCG 약한 양성이었으나 혈청 human chorionic

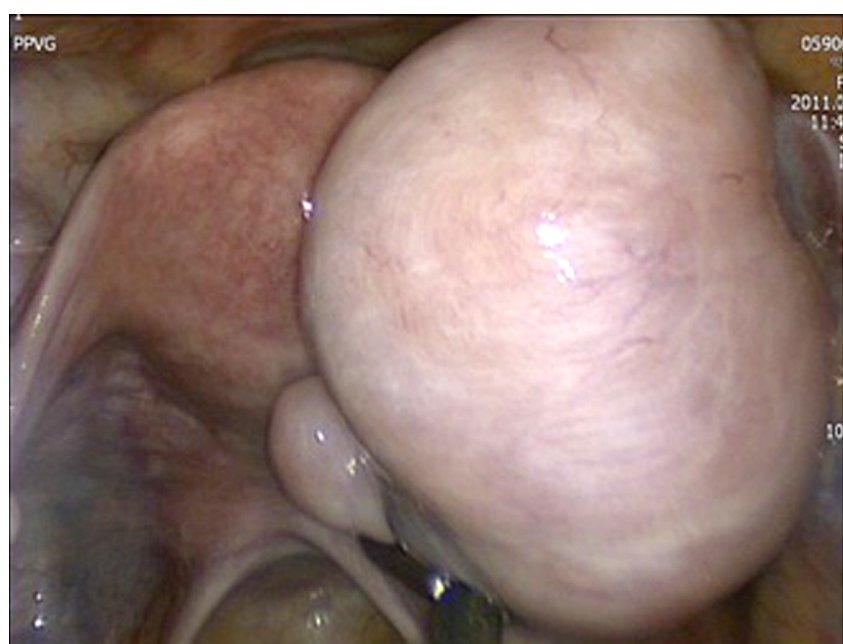

Fig. 3. Right ovarian tumor: operating finding.

gonadotropin, beta submit ( $\beta-\mathrm{hCG}$ )는 $4.11 \mathrm{mU} / \mathrm{mL}$ 였다. 그 외 일반 생화학검사, 혈액응고 검사, 혈청학 검사 및 요검사는 모두 정상 소견 이었다. 심전도 및 흉부 $X$ 선검사도 특이 소견 없었다.

초음파 소견: 질 초음파검사에서 자궁 뒤쪽으로 우측 부속기 주위에 $4.1 \mathrm{~cm}$ 의 전체적으로 저음영의 고형종이 보였고 정확한 정상 난소음 영은 관찰되지 않았다. 좌측 난소에 $1.9 \times 1.8 \mathrm{~cm}$ 의 고형종이 같이 보였 다. 자궁내막은 $5 \mathrm{~mm}$ 였고, 골반강내 체액 저류 등의 다른 특이 소견은 없었다(Fig. 1)

복강-골반 컴퓨터단층 소견: $5 \mathrm{~cm}$ 가량의 균질한 음영을 보이는 고형 종이 우측 부속기에서 관찰되었으며, 좌측 부속기와 자궁 및 단측면까 지 보이는 간과 양쪽 신장, 췌장, 비장에는 특이 소견 없었다(Fig. 2).

수술 소견: 전신마취하에 쇄석위 상태로 단일공하 복강경수술을 시행 하였다. 우측 난소의 대부분을 차지하는 $5 \mathrm{~cm}$ 가량의 고형종이 있었고 (Fig. 3), 정상 난소조직은 거의 보이지 않았다. 좌측 난소에는 $2 \mathrm{~cm}$ 가 량의 작은 결절이 관찰되었으며(Fig. 4), 그 외 자궁과 나팔관 및 골반 


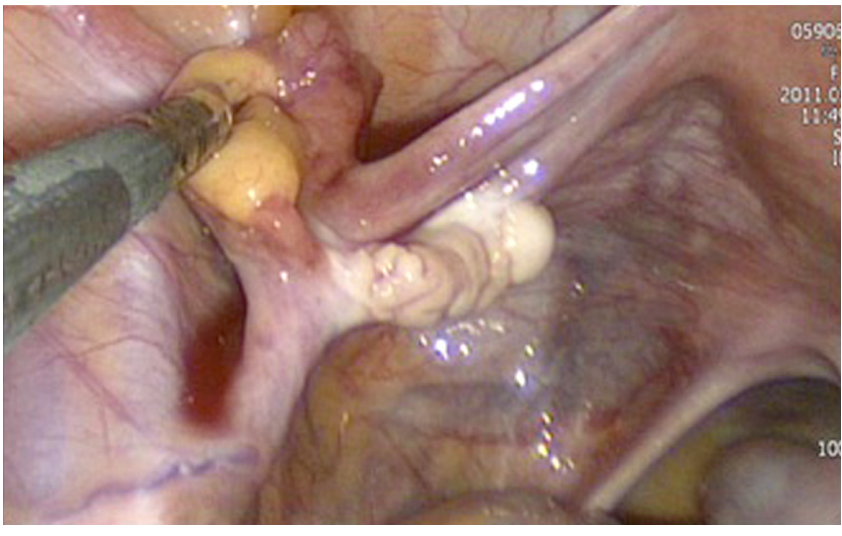

Fig. 4. Left ovarian nodules: operating finding.

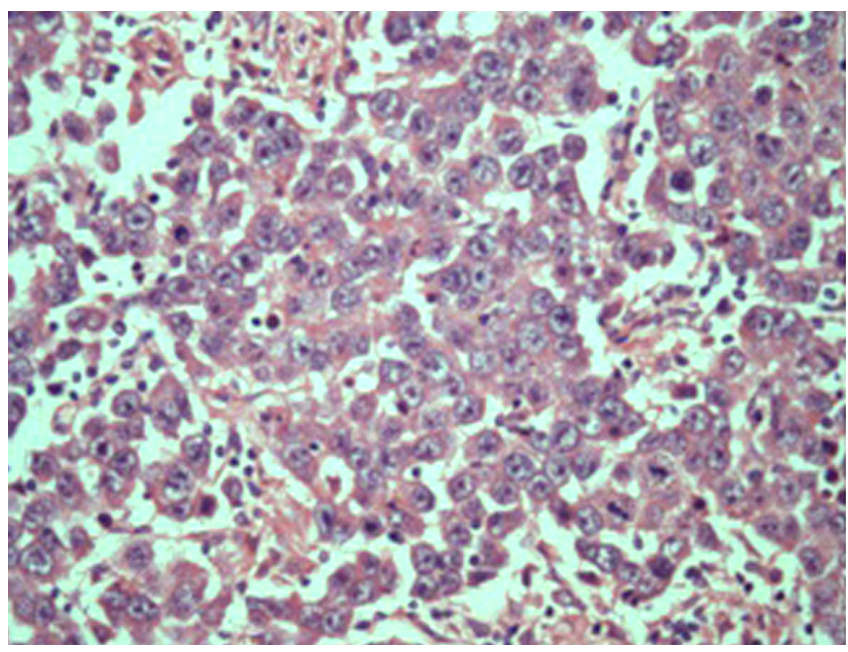

Fig. 5. Right ovarian dysgerminoma pathologic finding $\left(H \& E_{,} \times 400\right)$.

강내 특이 소견은 보이지 않았다. 종양을 포함하여 우측 부속기제거술 을 시행하였고, 응급으로 의뢰한 동결절편 조직검사상 미분화세포종이 보고되었고, 좌측 난소의 $2 \mathrm{~cm}$ 고형종이 있는 부위에 쐐기절제를 추 가로 시행하였으며, 동결절편조직검사에서 섬유종이 보고되었다. 수술 중 이상 출혈은 없었으며, 유착방지제 사용 후 수술을 종료하였다.

병리조직 소견: 제거한 조직에서 우측 난소의 $8.0 \times 4.0 \times 3.5 \mathrm{~cm}$ 크기 의 미분화세포종이 보고되었고, 종양막이 파열되지 않았고, 혈관의 종 양 혈전은 없었으며, 이로 인하여 임상적 병기 IA로 진단되었다(Fig. 5). 좌측 난소의 고형종은 섬유종(fibroma)으로 최종 진단되었다.

수술 후 경과: 수술 후 1일째 혈색소는 $10.8 \mathrm{~g} / \mathrm{dL}$ 이고 염색체검사상 46,XX로 정상이었다. 수술 후 활력 징후도 지속적으로 안정적으로 수 술 후 6 일째 특별한 합병증 없이 퇴원하였다. 수술 후 5 일째 시행한 luteinizing hormone $(\llcorner\mathrm{LH}) 6.95 \mathrm{mlU} / \mathrm{mL}$, follicular stimulating hormone (FSH) $44.64 \mathrm{mlU} / \mathrm{mL}$ 였고, 수술 후 13일째 외래에서 시행한 LH 19.49 $\mathrm{mlU} / \mathrm{mL}, \mathrm{FSH} 74.94 \mathrm{mlU} / \mathrm{mL}$, estradiol $10 \mathrm{pg} / \mathrm{mL}$ 미만, Anti-Müllerian hormone $0.51 \mathrm{ng} / \mathrm{mL}$ 로 죄측 난소 기능부전 소견을 보였다. 난소 미
분화세포종에 대하여 2011년 8월 1일을 시작으로 bleomycin (15 mg/ body surface area [BSA]), etoposide (100 mg/BSA), cispaltin (20 $\mathrm{mg} / \mathrm{BSA})$ 을 2011년 10월 29일까지 특이 합병증 없이 4차례 시행하였 고, 4 차 항암치료 시 시행한 질식 초음파상 특이 소견 없었으며, 이후 호르몬 대체 요법을 시작하였다. 향후 주기적인 외래 경과관찰 및 검사 계획 중이다.

\section{고 찰}

성선 이형성은 삭상 성선으로 남은 비정상적인 성선과 상승되어 있는 혈 중 성선자극호르몬을 특징으로 하며, 2차 성징의 지연 혹 은 부재를 보인다. 성선 이형성이 있는 경우 난소종양이 동반되는 경 우는 매우 드문 것으로, 동반되는 난소종양에는 난소 배아세포종 (gonadoblastoma)과 난소 미분화세포종이 가장 흔하다. 이 종양들은 잠재적 악성을 보이는 난소의 생식세포종양으로 늦지 않게 수술로 제 거되어야 한다[6,7].

성선 이형성과 동반된 난소 미분화세포종환자에서는 대개 $Y$ 염색체 혹은 $Y$ 모자이시즘 등의 염색체 이상 소견이 보고되고 있으며, 이와 관 련한 기전에 대해서는 여러 가설들이 있으며, $Y$ 염색체가 난소종양 발 생에 크게 관여하는 것으로 현재까지 알려져 오고있다[8]. 성선 이형 성증에서 $Y$ 염색체 없이 난소 미분화세포종이 발생된 예는 매우 드물 고, 거의 대부분에서 종양 발생의 원인으로 추정될 만한 $Y$ 염색체 혹은 $Y$ 모자이시즘이 함께 발견되었다[9]. 하지만, $45, X X$ 염색체 형을 가지 고 $Y$ 염색체가 없는 환자에서 난소 미분화세포종 발생한 경우도 드물 게 있다[10]. 저자들이 경험한 증례에서, $Y$ 염색체가 발견되지 않았지 만, 저자들의 염색체 분석법이 매우 작은 부분의 $Y$ 염색체 관련 인자를 규명하는데 제한적일 수 있음을 고려하여야 하므로, $Y$ 염색체 연관 관 련성을 완전히 배제할 수는 없다. 따라서, $Y$ 염색체상에서 성 결정부위 (sex-determining region of $Y$ chromosome)가 발견되지 않았다고 해 서 $Y$ 염색체가 없다거나, 환자가 종양이 발생할 위험이 증가되지 않는 다고 단정 지을 수는 없다.

성선 이형성과 난소종양의 동반에 있어 난소종양의 가족력 또한 매 우 중요한 요인 중 하나이다. 이전에 보고된 다른 증례를 보면, $Y$ 염 색체가 없는 $46, X X$ 의 정상 핵형이었으나, 쌍둥이 자매의 난소 기형종 (ovarian teratoma)의 뚜렷한 가족력을 가지고 있는 여성에서 난소 미 분화세포종이 발견된 바 있다. 그 기형종은 수술적 치료를 요했으며, 쌍둥이 자매의 난소생식세포종양(ovarian germ cell tumor) 기왕력은 환자의 난소 미분화세포종과의 발생학적 연관성을 제시하였다. 특히, 뚜렷한 $Y$ 염색체 인자가 발견되지 않은 환자에서는 난소종양의 가족 력이 더욱 난소종양 발생의 중요 영향 인자로 여겨질 가능성을 보여주 었다[10].

난소종양의 가족력은 성선 이형성이 진단되지 않은 경우라도 2차 성 징 지연, 혈중 성선자극호르몬 수치 상승과 에스트로겐의 수치 저하를 보이는 환자에게서 성선 이형성을 의심할 수 있게 한다. 난소종양의 가 


\section{KOREAN JOURNAL OF OBSTETRICS \& GYNECOLOGY}

So-yeon Yoon, et al. Dysgerminoma and gonadal dysgenesis

족력이 있는 경우, 생식세포종양(germ cell tumor)이 발견되었을 때는 이 가족력을 난소종양의 원인의 하나로 추측해 볼 수 있으며, 난소종양 의 가족력은 난소 미분화세포종을 가진 성선 이형성 환자에게서 $Y$ 염 색체가 발견되지 않은 경우에 특히 유용하므로 반드시 정확히 규명되 어야 한다.

본 증례 환자의 경우는 난소종양의 가족력과 뚜렷한 $Y$ 염색체 연관 인자가 없었으므로, 이 환자에게 발생한 난소 미분화세포종은 다른 인 자에 의한 것으로 여겨진다. 그러한 다른 요인으로는 상염색체 인자 혹 은 환경적 기형 발생 등을 생각해 볼 수 있다[11-13]. 이러한 이전 이 런 보고들은 $Y$ 염색체가 아닌 다른 요인에 의해 발생한 난소 생식세포 종양(germ cell tumor)의 가능성을 제시하고, $Y$ 염색체를 밝혀내는 것 이 반드시 필요한지를 다시 한번 생각하게 한다.

저자들은 본 증례에서 $46, X X$ 정상 염색체 핵형을 가진 여성에서 성 선 이형성과 난소 미분화세포종이 동반되어 발생한 예를 보고하였다. 지금까지 여러 문헌으로 보고된 성선 이형성과 난소 미분화세포종의 증례들은 대개 $Y$ 염색체 혹은 $Y$ 모자이시즘이 동반된 예들로, $Y$ 염색 체와 연관되지 않은 본 증례는 매우 드문 경우이다. 이전에 보고된 유 사한 증례들과 저자들의 경험에 비추어, 세포유전학 연구 시 $Y$ 염색체 규명이 의례적으로 반드시 필요한 것인가에 대하여 생각해 볼 수 있고, $Y$ 염색체가 성선 이형성과 난소 미분화세포종 발생에 필수 요인이라는 가설을 반문하게 한다. 향후 성선 이형성 환자에게 동반된 난소종양에 대한 발생학 원인 인자 및 $Y$ 염색체의 역할에 대한 보다 더 지속적이고 폭넓은 연구가 필요하다고 생각된다.

\section{References}

1. Rosen GF, Kaplan B, Lobo RA. Menstrual function and hirsutism in patients with gonadal dysgenesis. Obstet Gynecol 1988;71:677-80.

2. Donahoe PK, Crawford JD, Hendren WH. Mixed gonadal dysgenesis, pathogensis, and management. J Pediatr Surg
1979;14:287-300.

3. Tangjitgamol S, Hanprasertpong J, Manusirivithaya S, Wootipoom V, Thavaramara T, Buhachat R. Malignant ovarian germ cell tumors: clinico-pathological presentation and survival outcomes. Acta Obstet Gynecol Scand 2010;89:182-9.

4. Zalel Y, Piura B, Elchalal U, Czernobilsky B, Antebi S, Dgani R. Diagnosis and management of malignant germ cell ovarian tumors in young females. Int J Gynaecol Obstet 1996;55:1-10.

5. Troche V, Hernandez E. Neoplasia arising in dysgenetic gonads. Obstet Gynecol Surv 1986;41:74-9.

6. Sinisi AA, Perrone L, Quarto C, Barone M, Bellastella A, Faggiano $M$. Dysgerminoma in 45,X Turner syndrome: report of a case. Clin Endocrinol (Oxf) 1988;28:187-93.

7. Olsen MM, Caldamone AA, Jackson CL, Zinn A. Gonadoblastoma in infancy: indications for early gonadectomy in 46XY gonadal dysgenesis. J Pediatr Surg 1988;23:270-1.

8. Page DC. Hypothesis: a Y-chromosomal gene causes gonadoblastoma in dysgenetic gonads. Development 1987;101 Suppl:151-5.

9. Maeyama M, Kagami T, Miyakawa I, Tooya T, Kawasaki N, Iwamasa T. Case report of dysgerminoma in a patient with 46,XX pure gonadal dysgenesis. Gynecol Oncol 1983;16:405-13.

10. Letterie GS, Page DC. Dysgerminoma and gonadal dysgenesis in a 46,XX female with no evidence of $Y$ chromosomal DNA. Gynecol Oncol 1995;57:423-5.

11. Plattner $G$, Oxorn $H$. Familial incidence of ovarian dermoid cysts. Can Med Assoc J 1973;108:892-3.

12. Linder $D$, Hecht $F$, McCaw BK, Campbell JR. Origin of extragonadal teratomas and endodermal sinus tumours. Nature 1975;254:597-8.

13. Rayburn WF, Barr M Jr. Teratomas: concordance in mother and fetus. Am J Obstet Gynecol 1982;144:110-2. 


\section{정상 염색체 여성에서의 성선 이형성과 난소 미분화세포종이 동반된 1예}

${ }^{1}$ 성균관대학교 의과대학 삼성서울병원 산부인과학교실, 일신기독병원 ${ }^{2}$ 병리과, ${ }^{3}$ 산부인과

윤소연 ${ }^{1}$, 박향기 $\left.\right|^{1}$, 국진이 ${ }^{1}$, 옥순애 ${ }^{2}$, 박종훈 $^{3}$

성선 이형성(gonadal dysgenesis) 환자에게 난소종양이 동반되는 경우는 흔하지 않으며, 동반되는 종양 중 난소 배아세포종과 난소 미 분화세포종이 가장 흔하다. 이런 종양들은 대개 $Y$ 염색체 혹은 $Y$ 모자이시즘이 관련되어 있고, 정상 염색체를 보이는 경우는 보고된 예 가 극히 드물다. 저자들은 최근 임신력이 없는 미혼 29세 여성에서 일측 난소의 미분화세포종과 반대측 난소의 섬유종(fibroma), 난소기 능부전을 보이는 1예를 경험하였다. 수술 전 골반초음파, 복부-골반 컴퓨터단층촬영, 혈청학 lactate dehydrogenase (LDH), CA-125, CA 19-9 검사 후, 일측 난소, 나팔관제거술, 반대측 난소 쐐기절제술을 시행하였으며, 수술 후 혈청 follicular stimulating hormone 상승, $\mathrm{E}_{2}$ 감 소 소견이 보였다. 염색체검사는 46,XX로 정상이었으며, 병리 소견상 난소 미분화세포종이 보고되어 항암치료 및 호르몬 치료를 시행 중 에 있다. 이에 저자들은 $Y$ 염색체와 관련 없이 난소 미분화세포종과 난소기능부전을 동반한 드문 1 예를 경험하였기에 관련 문헌고찰과 함께 보고하는 바이다.

중심단어: 난소 미분화세포종, 성선 이형성, 정상 염색체 